\title{
Biomass and mortmass of woody vegetation in metal-contaminated areas (Southern Urals, Russia)
}

\author{
Igor Bergman ${ }^{\ddagger}$, Alexey Nesterkov $\ddagger$
}

$\ddagger$ Institute of plant and animal ecology, UB RAS, Ekaterinburg, Russia

Corresponding author: Igor Bergman (5554505@mail.ru), Alexey Nesterkov (nesterkov@ipae.uran.ru)

Academic editor: Ivan Chadin

Received: 20 Sep 2021 | Accepted: 12 Nov 2021 | Published: 29 Nov 2021

Citation: Bergman I, Nesterkov A (2021) Biomass and mortmass of woody vegetation in metal-contaminated areas (Southern Urals, Russia). Biodiversity Data Journal 9: e75510. https://doi.org/10.3897/BDJ.9.e75510

\section{Abstract}

\section{Background}

Since the mid-2000s, long-term monitoring of various components of natural ecosystems under conditions of industrial pollution has been carried out in the Southern Urals. As a part of these monitoring programmes, the data on various components of biota in different biotopes, collected with different methods and in different time intervals, continue to be gathered. In addition, data collected through these monitoring programmes can also be used to study the local biodiversity of non-polluted areas.

In 2012, in the vicinity of the Karabash Copper Smelter, a study of communities of small mammals was carried out, considering the heterogeneity of their habitats. Within the framework of this project, we presented a detailed description of the state of woody vegetation in the study area.

\section{New information}

The dataset (available from the GBIF network at https://www.gbif.org/dataset/ $61384 \mathrm{edd}-2 \mathrm{~d} 0 \mathrm{a}-437 \mathrm{~b}-8 \mathrm{cf0}-\mathrm{ff} 4 \mathrm{~d} 2 \mathrm{dfcc} 0 \mathrm{da})$ includes the results of an assessment of the 
woody vegetation biomass at seven habitats (pine, birch and floodplain forests, reed swamp, sparse birch stand, marshy meadow and dump of household waste) of areas with different levels of industrial pollution in the vicinities of the Karabash, the Southern Urals. Karabash Copper Smelter (KCS) is one of Russia's most significant point polluters; the main components of its emissions are heavy metals, dust and sulphur dioxide. Parameters of woody vegetation (diameter at breast height, diameter at root collar level and biomass) were estimated for seven forest elements (forest stand, subcanopy (undergrowth and underwood), half-dead tree of a forest stand and four types of coarse woody debris (downed bole, fragment of downed bole, standing dead tree and stump)) at 41 sampling plots (20 at unpolluted and 21 at polluted areas) and 165 subplots (81 and 84 , respectively). The dataset includes 411 sampling events (estimation events of the forest elements at sampling plots and subplots), corresponding to 5786 occurrences (estimations of the woody vegetation components) observed during July 2012. For most woody vegetation components (72\%), an estimate of the above-ground phytomass is given. For each sampling event, information on the presence or absence of woody vegetation species at the considered habitats is provided (a total of 1479 occurrences with status "absent"). The dataset can be used for environmental monitoring, sustainable forest management, modelling forest productivity considering global changes, studying the structure and biodiversity of forest cover and assessing forests' carbon-sequestration capacity. In addition, the dataset provides information about different forest ecosystems under the influence of strong industrial pollution.

\section{Keywords}

aerial pollution, biodiversity, biomass, biotope, coarse woody debris (CWD), copper smelter, standing dead tree, downed bole, diameter at breast height $(\mathrm{DBH})$, forest stand, mortmass, phytomass, stump, subcanopy

\section{Introduction}

To study the reaction of biota's components to technogenic pollution, the biotope that dominates in the region and is represented in the entire pollution gradient is traditionally chosen. As a rule, this approach indicates an apparent decrease in biodiversity, abundance and biological productivity when proceeded towards the source of industrial emissions. However, in reality, the territories subjected to severe technogenic pollution are not a lifeless desert, but a mosaic of various biotopes (Mukhacheva et al. 2013). Therefore, studying the entire complex of biotopes of contaminated areas, one can come to fundamentally different conclusions of the biota's response to pollution compared to the traditional approach. For example, in the near vicinities of the Karabash Copper Smelter (KCS), significantly degraded, almost lifeless areas coexist and alternate with relatively preserved biotopes that provide a wide range of small mammal species, although their numbers are reduced compared to non-polluted territories. It was shown that this environmental heterogeneity plays a crucial role in the small mammal's diversity preservation under severe technogenic pollution (Mukhacheva et al. 2013); a similar result 
was obtained when studying the forest stands. An essential indicator of the forest stand's state, the proportion of large trees (diameter at breast height is more than $20 \mathrm{~cm}$ ) in pine and birch forests near the KCS was decreased as expected. However, on the contrary, in the floodplain stands of the polluted territory, the proportion of large trees increased and, in sparse birch stands, did not differ in the pollution gradient (Bergman et al. 2013).

The dataset includes information on the main woody vegetation parameters in seven types of habitats in areas with different levels of technogenic pollution. The presented data provide an opportunity to analyse the resistance of woody vegetation to technogenic pollution, considering the heterogeneity within the studied areas. The dataset contains the following parameters: species diversity and the number of woody plants, trunk diameters, above-ground phytomass (for living representatives) and mortmass of trunks (for dead representatives).

For most woody vegetation elements $(72 \%)$ represented in the dataset, an estimate of the above-ground phytomass is given. The forest phytomass is the main parameter that determines the course of processes in forest ecosystems. It is used for environmental monitoring, sustainable forest management, modelling forest productivity taking into account global changes, studying the structure and biodiversity of forest cover and assessing forests' carbon-sequestration capacity (Fowler et al. 2002).

The dataset provides information for studying the regularities of the biogenic carbon cycle as the main component of the global carbon cycle, the most crucial problem of modern ecology. This direction has acquired particular relevance in recent years in connection with regional and global climate changes. An assessment of the carbon balance is impossible without correct data on its content in each of the pools of the forest ecosystem, in particular, in the above-ground phytomass and mortmass of woody vegetation. For each of the biotopes presented in the dataset, coarse woody debris (CWD) is considered. CWD is understood as the dead matter of tree trunks (standing dead trees, downed boles, stumps) of all stages of decomposition, up to its transition to detritus. CWD is also a source of nutrients entering the soil, a source of food, a habitat for many species of animals, plants and fungi (Stokland et al. 2012, Bobkova et al. 2015). Interest in the study of CWD is not accidental and is due to its importance in the analysis of carbon sequestration processes ( Karjalainen and Kuuluvainen 2002, Zamolodchikov 2009), as well as in the development of programmes for the conservation of forest ecosystem biodiversity (Siitonen 2001, Stokland et al. 2012). Considering, on the one hand, the apparent need for correct estimates of all components of the carbon balance and, on the other hand, the fact that industrially polluted areas are convenient for analysing the ecosystems resilience to strong impacts, the presented dataset has a "direct access" to operational issues of regional and global environmental changes discussed by the scientific community.

\section{Project description}

Study area description: The Ural Mountains are a north-south-orientated mountain system in the Urals, located between the East European and West Siberian plains. The 
study area is located in the lowest uplands (300-400 m altitude above sea level) in the southern taiga subzone. The prevailing forest types are herb pineries and secondary grass herb birch forests with linden, aspen and larch populations. The main soil types are brown mountain-forest and forest soils, grey soils, mountain-forest and mountain-podzol chernozems. The climate is continental, moderately cold. The annual temperature is $1.8^{\circ} \mathrm{C}$ and the average precipitation is $450-550 \mathrm{~mm}$. The duration of the vegetation period is $160-170$ days and the average height of the snow cover is about $40 \mathrm{~cm}$.

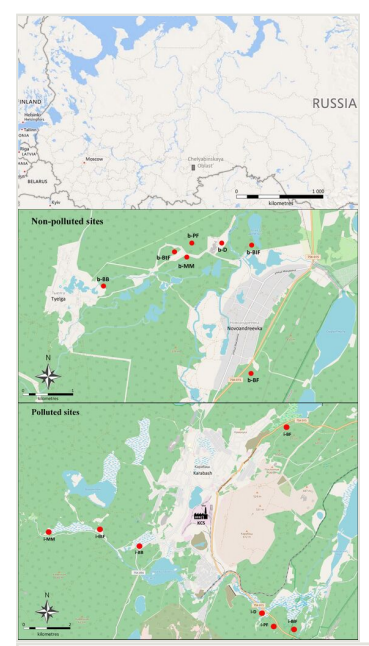

Figure 1. doi

Location of the studied habitats at non-polluted and polluted areas in the vicinities of Karabash Copper Smelter, Southern Urals (data from Open Street Map; abbreviations of the habitats correspond to those in the dataset and Table 1).

Table 1.

Habitat types and location of the sampling plots (coordinates of centres are given; dash denotes absence of the sampling plot: only two plots were established at the reed swamp of non-polluted area).

\begin{tabular}{|c|c|c|c|c|c|c|c|c|}
\hline \multirow[t]{2}{*}{ Habitat } & \multicolumn{4}{|c|}{ Non-polluted sites } & \multicolumn{4}{|c|}{ Polluted sites } \\
\hline & $\begin{array}{c}\text { Sampling } \\
\text { plot }\end{array}$ & $\begin{array}{c}\text { Decimal } \\
\text { longitude }\end{array}$ & $\begin{array}{l}\text { Decimal } \\
\text { latitude }\end{array}$ & $\begin{array}{c}\text { Elevation, } \\
\text { m a.s.I. }\end{array}$ & $\begin{array}{c}\text { Sampling } \\
\text { plot }\end{array}$ & $\begin{array}{c}\text { Decimal } \\
\text { longitude }\end{array}$ & $\begin{array}{l}\text { Decimal } \\
\text { latitude }\end{array}$ & $\begin{array}{c}\text { Elevation, } \\
\text { m a.s.I. }\end{array}$ \\
\hline \multirow{3}{*}{$\begin{array}{l}\text { Pine forest } \\
\text { (PF) }\end{array}$} & b-PF-1 & 55.3437 & 60.2078 & 296 & i-PF-1 & 55.4282 & 60.2547 & 298 \\
\hline & b-PF-2 & 55.3441 & 60.2091 & 320 & i-PF-2 & 55.4280 & 60.2559 & 312 \\
\hline & b-PF-3 & 55.3437 & 60.2097 & 307 & i-PF-3 & 55.4272 & 60.2564 & 303 \\
\hline \multirow{3}{*}{$\begin{array}{l}\text { Birch forest } \\
\text { (BF) }\end{array}$} & b-BF-1 & 55.3226 & 60.2263 & 366 & i-BF-1 & 55.4993 & 60.2609 & 350 \\
\hline & b-BF-2 & 55.3223 & 60.2262 & 335 & i-BF-2 & 55.4991 & 60.2607 & 360 \\
\hline & b-BF-3 & 55.3222 & 60.2259 & 361 & i-BF-3 & 55.4985 & 60.2607 & 367 \\
\hline
\end{tabular}




\begin{tabular}{|c|c|c|c|c|c|c|c|c|}
\hline \multirow[t]{2}{*}{ Habitat } & \multicolumn{4}{|c|}{ Non-polluted sites } & \multicolumn{4}{|c|}{ Polluted sites } \\
\hline & $\begin{array}{l}\text { Sampling } \\
\text { plot }\end{array}$ & $\begin{array}{c}\text { Decimal } \\
\text { longitude }\end{array}$ & $\begin{array}{l}\text { Decimal } \\
\text { latitude }\end{array}$ & $\begin{array}{c}\text { Elevation, } \\
\text { m a.s.I. }\end{array}$ & $\begin{array}{l}\text { Sampling } \\
\text { plot }\end{array}$ & $\begin{array}{c}\text { Decimal } \\
\text { longitude }\end{array}$ & $\begin{array}{l}\text { Decimal } \\
\text { latitude }\end{array}$ & $\begin{array}{c}\text { Elevation, } \\
\text { m a.s.I. }\end{array}$ \\
\hline \multirow{3}{*}{$\begin{array}{l}\text { Floodplain } \\
\text { forest } \\
\text { (BIF) }\end{array}$} & b-BIF-1 & 55.3436 & 60.2257 & 287 & i-BIF-1 & 55.4232 & 60.2714 & 279 \\
\hline & b-BIF-2 & 55.3440 & 60.2270 & 294 & i-BIF-2 & 55.4238 & 60.2717 & 283 \\
\hline & b-BIF-3 & 55.3437 & 60.2281 & 305 & i-BIF-3 & 55.4232 & 60.2733 & 276 \\
\hline \multirow{3}{*}{$\begin{array}{l}\text { Reed } \\
\text { swamp } \\
\text { (BB) }\end{array}$} & b-BB-1 & 55.3365 & 60.1823 & 297 & i-BB-1 & 55.4565 & 60.1695 & 329 \\
\hline & b-BB-2 & 55.3371 & 60.1825 & 296 & i-BB-2 & 55.4564 & 60.1695 & 330 \\
\hline & - & - & - & - & i-BB-3 & 55.4566 & 60.1697 & 331 \\
\hline \multirow{3}{*}{$\begin{array}{l}\text { Sparse } \\
\text { birch stand } \\
\text { (BtF) }\end{array}$} & b-BtF-1 & 55.3435 & 60.2062 & 296 & i-BtF-1 & 55.4623 & 60.1432 & 320 \\
\hline & b-BtF-2 & 55.3428 & 60.2055 & 288 & i-BtF-2 & 55.4621 & 60.1440 & 321 \\
\hline & b-BtF-3 & 55.3427 & 60.2048 & 296 & i-BtF-3 & 55.4613 & 60.1441 & 324 \\
\hline \multirow{3}{*}{$\begin{array}{l}\text { Marshy } \\
\text { meadow } \\
(\mathrm{MM})\end{array}$} & b-MM-1 & 55.3426 & 60.2076 & 297 & i-MM-1 & 55.4610 & 60.1108 & 339 \\
\hline & b-MM-2 & 55.3424 & 60.2056 & 301 & i-MM-2 & 55.4607 & 60.1101 & 337 \\
\hline & b-MM-3 & 55.3433 & 60.2061 & 291 & i-MM-3 & 55.4610 & 60.1092 & 337 \\
\hline \multirow{3}{*}{$\begin{array}{l}\text { Waste dump } \\
\text { (D) }\end{array}$} & b-D-1 & 55.3437 & 60.2171 & 289 & i-D-1 & 55.4319 & 60.2498 & 289 \\
\hline & b-D-2 & 55.3443 & 60.2176 & 290 & i-D-2 & 55.4317 & 60.2495 & 292 \\
\hline & $b-D-3$ & 55.3435 & 60.2178 & 292 & i-D-3 & 55.4322 & 60.2500 & 291 \\
\hline
\end{tabular}

\section{Sampling methods}

Study extent: The study was carried out in vicinities of the Karabash Copper Smelter (55.469 N, 60.209 E), located within the City of Karabash (90 km northwest of Chelyabinsk, Southern Urals). A total of 41 sampling plots were established in seven types of habitats: pine, birch and floodplain forests, reed swamp, sparse birch stand, marshy meadow and dump of household waste. All habitats were surveyed using six sampling plots, except for the reed swamp (five plots). The study was completed in July 2012.

\section{Sampling description: The survey of forest woody vegetation at sampling plots}

The survey of forest woody vegetation is the leading and only method of accounting for forest resources, making possible the quantitative and qualitative evaluation of the forest health.

During the survey, we identified the following forest elements (according to Harmon et al. 2004):

1. the forest stand - living trees with a diameter at breast height $(\mathrm{DBH})$ of more than 5 $\mathrm{cm}$; 
2. the subcanopy - all living trees with $\mathrm{DBH}$ of less than $5 \mathrm{~cm}$ and height of more than 10 $\mathrm{cm}$; this forest element includes the undergrowth (trees, capable of forming the forest stand) and underwood (bushes, not capable of forming the forest stand);

3. the half-dead tree - the main trunk of which died, but branches with leaves emerge from the dormant buds preserved at the trunk. All detected trees were assigned to the forest stand;

4. the standing dead tree - dead but not fallen trees with a $\mathrm{DBH}$ no less than $5 \mathrm{~cm}$ and height more than $2 \mathrm{~m}$;

5. the stump - lower part of the dead tree trunk, less than $2 \mathrm{~m}$ in height. The diameter was usually measured at the point of breaking of a tree trunk;

6. the downed bole - a fallen/hung tree trunk (or part of it), which is entirely within the sampling plot;

7. the fragment of a downed bole - a fallen tree trunk (or part of it), which is partially within the sampling plot (only the part within the plot was taken into account).

The information about the forest element type is encoded in the eventID and occurrencelD. The authors tried to establish the sampling plots so that the anthropogenic impact (recreation, grazing, felling, haymaking) was minimal. Three sampling plots with a size of $25 \times 25 \mathrm{~m}$ were established within each type of habitat, except for the reed swamp (two plots at the unpolluted area, see Table 1). When the habitat configuration did not allow arranging a rectangular sampling plot, its size could vary within 471-691 $\mathrm{m}^{2}$. Complete estimation of forest woody vegetation was performed at each site in both the subcanopy and forest stand. The trees in the forest stand were estimated throughout the entire sampling plot. An estimation of trees in the subcanopy was carried out at 1-10 subplots of 1-34 $\mathrm{m}^{2}$ selected within the sampling plot, depending on the biotope (Table 2).

Table 2.

Numbers of sampling plots and subplots in different habitats at non-polluted and polluted areas.

\begin{tabular}{|c|c|c|c|c|c|}
\hline Habitat & $\begin{array}{l}\text { Area of } \\
\text { pollution }\end{array}$ & $\begin{array}{l}\text { Number of } \\
\text { sampling plots }\end{array}$ & $\begin{array}{l}\text { Number of subplots } \\
\text { at each sampling plot }\end{array}$ & $\begin{array}{l}\text { Size of } \\
\text { subplots, m }\end{array}$ & Remarks \\
\hline \multirow[t]{2}{*}{$\begin{array}{l}\text { Birch forest } \\
\text { (BF) }\end{array}$} & $\begin{array}{l}\text { Non- } \\
\text { polluted }\end{array}$ & 3 & $9(3 \times 3)$ & $5 \times 5$ & \\
\hline & Polluted & 3 & $9(3 \times 3)$ & $5 \times 5$ & $\begin{array}{l}\text { Heaps of dry branches, } \\
\text { data on which are not } \\
\text { included in the dataset. }\end{array}$ \\
\hline \multirow[t]{2}{*}{$\begin{array}{l}\text { Pine forest } \\
\text { (PF) }\end{array}$} & $\begin{array}{l}\text { Non- } \\
\text { polluted }\end{array}$ & 3 & $9(3 \times 3)$ & $5 \times 5$ & \\
\hline & Polluted & 3 & $9(3 \times 3)$ & $5 \times 5$ & $\begin{array}{l}\text { The local population } \\
\text { probably withdraws some } \\
\text { downed boles. }\end{array}$ \\
\hline \multirow[t]{2}{*}{$\begin{array}{l}\text { Floodplain } \\
\text { forest (BIF) }\end{array}$} & $\begin{array}{l}\text { Non- } \\
\text { polluted }\end{array}$ & 3 & $9(3 \times 3)$ & $5 \times 5$ & \\
\hline & Polluted & 3 & $9(3 \times 3)$ & $5 \times 5$ & $\begin{array}{l}\text { Some downed boles with } \\
\text { saw marks. }\end{array}$ \\
\hline
\end{tabular}




\begin{tabular}{|c|c|c|c|c|c|}
\hline Habitat & $\begin{array}{l}\text { Area of } \\
\text { pollution }\end{array}$ & $\begin{array}{l}\text { Number of } \\
\text { sampling plots }\end{array}$ & $\begin{array}{l}\text { Number of subplots } \\
\text { at each sampling plot }\end{array}$ & $\begin{array}{l}\text { Size of } \\
\text { subplots, m }\end{array}$ & Remarks \\
\hline \multirow[t]{2}{*}{$\begin{array}{l}\text { Reed swamp } \\
\text { (BB) }\end{array}$} & $\begin{array}{l}\text { Non- } \\
\text { polluted }\end{array}$ & 2 & $6(2 \times 3)$ & $5 \times 5$ & \\
\hline & Polluted & 3 & $9(3 \times 3)$ & $5 \times 5$ & \\
\hline \multirow[t]{2}{*}{$\begin{array}{l}\text { Sparse birch } \\
\text { stand (BtF) }\end{array}$} & $\begin{array}{l}\text { Non- } \\
\text { polluted }\end{array}$ & 3 & $30(3 \times 10)$ & $1 \times 1$ & $\begin{array}{l}\text { Periodic grass mowing. } \\
\text { Heaps of dry branches } \\
\text { not included in the } \\
\text { dataset. }\end{array}$ \\
\hline & Polluted & 3 & $30(3 \times 10)$ & $1 \times 1$ & \\
\hline \multirow{2}{*}{$\begin{array}{l}\text { Marshy } \\
\text { meadow } \\
(\mathrm{MM})\end{array}$} & $\begin{array}{l}\text { Non- } \\
\text { polluted }\end{array}$ & 3 & $15(3 \times 5)$ & $13 \times 6$ & Periodic grass mowing. \\
\hline & Polluted & 3 & $15(3 \times 5)$ & $13 \times 6$ & \\
\hline \multirow[t]{2}{*}{$\begin{array}{l}\text { Waste dump } \\
\text { (D) }\end{array}$} & $\begin{array}{l}\text { Non- } \\
\text { polluted }\end{array}$ & 3 & $3(3 \times 1)$ & $8.4 \times 4.0$ & \\
\hline & Polluted & 3 & $3(3 \times 1)$ & $8.4 \times 4.0$ & \\
\hline
\end{tabular}

The distance between the sampling plots in the birch, pine and floodplain forests and the sparse birch stand was 15-40 $\mathrm{m}$. Therefore, subplots in these habitats were arranged randomly: the site was divided into equal squares $5 \times 5 \mathrm{~m}(1 \times 1 \mathrm{~m}$ for the sparse birch stand); each square was assigned a number. Then, three cards (except for some cases, see Table 2) with a number were selected randomly and the corresponding subplots within the sampling plot were approved. The reed swamp and marshy meadow were of limited size: in these habitats, the distance between sampling plots was several metres; in some cases, plots were adjacent to each other. The location of subplots within the sampling plot was uniform. For the waste dump, only one subplot within each sampling plot was established at places where above-ground vegetation was detected.

In the forest stand, a caliper with a scale up to $1 \mathrm{~cm}$ was used to measure the trunk diameters. Tree specimens with a diameter at breast height $(1.3 \mathrm{~m})$ equal to $5 \mathrm{~cm}$ or more were taken into account. Diameter measurements were taken in two mutually perpendicular directions, with the subsequent calculation of the arithmetic mean diameter. The diameters of the standing dead trees and half-dead trees were measured in the same way. The stump diameters were measured at the fracture point using a caliper in two mutually perpendicular directions. Stumps with a base diameter of more than $5 \mathrm{~cm}$ were taken into account. Next, the diameter of the subcanopy trees was measured at the level of the root collar using a pole caliper with an accuracy of $0.1 \mathrm{~cm}$. Finally, the downed boles and fragments of downed boles were measured using a caliper: the base and the top diameters of the downed boles $(\mathrm{cm})$ and its length $(\mathrm{m})$ were measured.

The volume of downed bole $\left(\mathrm{V}_{\mathrm{dbole}}\right)$ was calculated using a modified truncated cone volume equation:

$$
V_{\text {dbole }}=1 / 3 \pi \times H\left(R_{\text {base }}^{2}+R_{\text {base }} \times R_{\text {top }}+R_{\text {top }}^{2}\right)
$$


where $\mathrm{H}$ - length of a downed bole, $\mathrm{m}$; $\mathrm{R}_{\text {base }}$ - base radius of a downed bole, $\mathrm{m} ; \mathrm{R}_{\text {top }}$ - top radius of a downed bole, $\mathrm{m}$ (these three parameters are not included in the dataset, but are available upon request). The advantage of this formula is its simplicity (only three parameters are involved) and forest ecologists widely use it to assess downed bole biomass rapidly. The volume $\left(\mathrm{m}^{3}\right)$ of each downed bole that falls within the sampling plot (a whole or a fragment) was calculated.

To calculate the above-ground phytomass of trees of the forest stand, subcanopy and standing dead trees in each habitat type, we used our data obtained and published earlier, which represent a detailed characterisation of the model trees (Usoltsev et al. 2012). A detailed description of the methods for determining the above-ground phytomass of model trees is given below. These data served as the basis for constructing regression equations and subsequent evaluation of the above-ground phytomass of each tree specimen in each habitat type.

For tree species of the forest stand, subcanopy and standing dead trees, the calculation of the parameters of the regression equations were performed by the formula (Kofman 1986):

\section{$P_{\text {phytomass }}=a_{1} \times D^{a_{2}}$}

where $\mathrm{P}_{\text {phytomass }}$ - absolute dry above-ground phytomass of the plant, $\mathrm{kg}$; $\mathrm{D}$ - diameter of the trunk, $\mathrm{cm}$ (for forest stand and standing dead trees measured at the height of $1.3 \mathrm{~m}$, for subcanopy measured at root collar level); $a_{1}$ and $a_{2}-$ constants of the equation. This type of regression is considered to be the most biologically determined (Kofman 1986). Equation constants are selected by the non-linear estimation method (LevenbergMacwardt algorithm). The procedure is implemented in STATISTICA v.8.0. Thus, the biomass of each woody plant can be efficiently and reliably estimated by the size of the trunk diameter using the presented dependence equations (Table 3).

Table 3.

Constants $\left(a_{1}\right.$ and $\left.a_{2}\right)$ of regression equations for woody vegetation species of the different forest elements (constants are selected by Levenberg-Macwardt algorithm; $R^{2}$ - coefficient of determination, $\mathrm{n}$ - number of sampling units (trees)).

\begin{tabular}{|c|c|c|c|c|c|c|c|}
\hline $\begin{array}{l}\text { Forest } \\
\text { element }\end{array}$ & Species & $a_{1}$ & $a_{2}$ & $\mathrm{R}^{2}$ & $\mathrm{n}$ & Collected at & Source \\
\hline \multirow[t]{4}{*}{ Subcanopy } & $\begin{array}{l}\text { Chamaecytisus } \\
\text { ruthenicus }\end{array}$ & 0.040593 & 2.17829 & 0.94 & 17 & $\begin{array}{c}\text { Chelyabinskaya oblast', } \\
\text { Southern taiga }\end{array}$ & $\begin{array}{l}\text { Usoltsev et } \\
\text { al. } 2012\end{array}$ \\
\hline & Sorbus aucuparia & 0.025749 & 3.28474 & 0.99 & 12 & $\begin{array}{c}\text { Chelyabinskaya oblast', } \\
\text { Southern taiga }\end{array}$ & $\begin{array}{l}\text { Usoltsev et } \\
\text { al. } 2012\end{array}$ \\
\hline & $\begin{array}{l}\text { Sorbus aucuparia } \\
\text { (large trees) }\end{array}$ & 0.050513 & 2.69275 & 0.99 & 4 & $\begin{array}{c}\text { Sverdlovskaya oblast', } \\
\text { Southern taiga }\end{array}$ & $\begin{array}{l}\text { Usoltsev et } \\
\text { al. } 2018\end{array}$ \\
\hline & Rubus idaeus & 0.01467 & 2.00523 & 0.71 & 6 & $\begin{array}{c}\text { Sverdlovskaya oblast', } \\
\text { Southern taiga }\end{array}$ & $\begin{array}{l}\text { Usoltsev et } \\
\text { al. } 2012\end{array}$ \\
\hline
\end{tabular}




\begin{tabular}{|c|c|c|c|c|c|c|c|}
\hline $\begin{array}{c}\text { Forest } \\
\text { element }\end{array}$ & Species & $a_{1}$ & $a_{2}$ & $\mathrm{R}^{2}$ & $\mathrm{n}$ & Collected at & Source \\
\hline & Rosa majalis & 0.060674 & 2.78288 & 0.95 & 10 & $\begin{array}{l}\text { Chelyabinskaya and } \\
\text { Sverdlovskaya oblast', } \\
\text { Southern taiga }\end{array}$ & $\begin{array}{l}\text { Usoltsev et } \\
\text { al. } 2012\end{array}$ \\
\hline & Pinus sylvestris & 0.017878 & 2.92874 & 0.97 & 27 & $\begin{array}{l}\text { Chelyabinskaya oblast', } \\
\text { Southern taiga }\end{array}$ & $\begin{array}{l}\text { Usoltsev et } \\
\text { al. } 2012\end{array}$ \\
\hline & Betula sp. & 0.023576 & 3.15147 & 0.96 & 18 & $\begin{array}{l}\text { Chelyabinskaya oblast', } \\
\text { Southern taiga }\end{array}$ & $\begin{array}{l}\text { Usoltsev et } \\
\text { al. } 2012\end{array}$ \\
\hline & Populus tremula & 0.03445 & 3.08644 & 0.90 & 12 & $\begin{array}{l}\text { Chelyabinskaya oblast', } \\
\text { Southern taiga }\end{array}$ & $\begin{array}{l}\text { Usoltsev et } \\
\text { al. } 2012\end{array}$ \\
\hline & Alnus incana & 0.017657 & 3.27133 & 0.99 & 7 & $\begin{array}{l}\text { Chelyabinskaya oblast', } \\
\text { Southern taiga }\end{array}$ & $\begin{array}{l}\text { Usoltsev et } \\
\text { al. } 2012\end{array}$ \\
\hline & Abies sibirica & 0.052977 & 2.40134 & 0.96 & 23 & $\begin{array}{l}\text { Sverdlovskaya oblast', } \\
\text { Southern taiga }\end{array}$ & $\begin{array}{l}\text { Usoltsev et } \\
\text { al. } 2012\end{array}$ \\
\hline & Prunus padus & 0.065709 & 1.90958 & 0.99 & 7 & $\begin{array}{l}\text { Chelyabinskaya oblast', } \\
\text { Southern taiga }\end{array}$ & $\begin{array}{l}\text { Usoltsev et } \\
\text { al. } 2012\end{array}$ \\
\hline & $\begin{array}{l}\text { Cotoneaster } \\
\text { lucidus }\end{array}$ & 0.041403 & 2.73328 & 0.78 & 8 & $\begin{array}{l}\text { Chelyabinskaya oblast', } \\
\text { Southern taiga }\end{array}$ & $\begin{array}{l}\text { Usoltsev et } \\
\text { al. } 2012\end{array}$ \\
\hline & Salix caprea & 0.033553 & 2.67063 & 0.99 & 3 & $\begin{array}{l}\text { Sverdlovskaya oblast', } \\
\text { Southern taiga }\end{array}$ & $\begin{array}{l}\text { Usoltsev et } \\
\text { al. } 2012\end{array}$ \\
\hline \multirow[t]{5}{*}{ Forest stand } & Betula sp. & 0.098613 & 2.53413 & 0.97 & 56 & $\begin{array}{l}\text { Chelyabinskaya oblast', } \\
\text { Southern taiga }\end{array}$ & $\begin{array}{l}\text { Usoltsev et } \\
\text { al. } 2012\end{array}$ \\
\hline & Pinus sylvestris & 0.12004 & 2.38449 & 0.97 & 40 & $\begin{array}{l}\text { Chelyabinskaya oblast', } \\
\text { Southern taiga }\end{array}$ & $\begin{array}{l}\text { Usoltsev et } \\
\text { al. } 2012\end{array}$ \\
\hline & Picea obovata & 0.321051 & 2.04809 & 0.97 & 33 & $\begin{array}{l}\text { Chelyabinskaya oblast', } \\
\text { Southern taiga }\end{array}$ & $\begin{array}{l}\text { Usoltsev et } \\
\text { al. } 2012\end{array}$ \\
\hline & Populus tremula & 0.14492 & 2.30065 & 0.99 & 5 & Southern Karelia, Middle taiga & $\begin{array}{l}\text { Usoltsev et } \\
\text { al. } 2018\end{array}$ \\
\hline & Alnus incana & 0.065389 & 2.4907 & 0.99 & 17 & $\begin{array}{l}\text { Vologodskaya oblast', Middle } \\
\text { taiga }\end{array}$ & $\begin{array}{l}\text { Usoltsev et } \\
\text { al. } 2018\end{array}$ \\
\hline \multirow[t]{3}{*}{$\begin{array}{l}\text { Standing dead } \\
\text { trees }\end{array}$} & Betula sp. & 0.12954 & 2.39547 & 0.99 & 56 & $\begin{array}{l}\text { Chelyabinskaya oblast', } \\
\text { Southern taiga }\end{array}$ & $\begin{array}{l}\text { Usoltsev et } \\
\text { al. } 2012\end{array}$ \\
\hline & Pinus sylvestris & 0.130432 & 2.31176 & 0.96 & 40 & $\begin{array}{l}\text { Chelyabinskaya oblast', } \\
\text { Southern taiga }\end{array}$ & $\begin{array}{l}\text { Usoltsev et } \\
\text { al. } 2012\end{array}$ \\
\hline & Alnus incana & 0.068865 & 2.47813 & 0.99 & 5 & Southern Karelia, Middle taiga & $\begin{array}{l}\text { Usoltsev et } \\
\text { al. } 2018\end{array}$ \\
\hline
\end{tabular}

Due to restrictions from the Forestry authorities, the following tree species were prohibited for felling: in the forest stand - Acer negundo, Alnus incana, Crataegus sanguinea, Larix sibirica, Malus baccata, Populus tremula, Prunus padus, all species of Salix and Ulmus and all half-dead trees; in the subcanopy - Acer negundo, Larix sibirica, all species of Salix (except for Salix caprea) and Viburnum opulus. Biomass for Alnus incana (including the 
mortmass of downed boles of this species) and Populus tremula was estimated using literature data (Usoltsev et al. 2018).

The mortmass of the downed bole $\left(P_{\text {mort }}\right)$ was calculated, based on the volume estimations:

$\mathbf{P}_{\text {mort }}=\mathbf{V}_{\text {mort }} \times \mathbf{p}_{\text {mort }}$

where $\mathrm{P}_{\text {mort }}$ - absolute dry mortmass, $\mathrm{kg} ; \mathrm{V}_{\text {mort }}-$ the volume of downed bole, $\mathrm{m}^{3} ; \mathrm{p}_{\text {mort }}-$ average density of moderately decomposed downed bole, $\mathrm{kg} / \mathrm{m}^{3}$. The data on downed bole densities were taken as constants from literature sources (Klimchenko et al. 2011) for dead pine (constant for downed bole of coniferous trees, $0.307 \mathrm{~kg} / \mathrm{m}^{3}$ ) and birch (constant for downed bole of deciduous trees, $0.428 \mathrm{~kg} / \mathrm{m}^{3}$ ), as these species predominate in the territory of our study.

\section{A detailed description of methods for determining the above-ground phytomass of model trees}

The processing of model trees was carried out in August 2010 outside the sampling plots under consideration according to the following method (Usoltsev and Zalesov 2005).

Model trees of each species were selected in such a way as to cover the entire range of variation in their diameters, from minimum values to maximum values. The model trees were felled in August 2010 when the foliage/needles of the current year were fully formed. After felling, the tree's length was measured. First, the trunk was divided into ten sections. Then, in the middle of each section, measuring from the butt, discs were cut out making it possible to define the diameter of the trunk in the bark and without bark. These measurements were used to calculate the volumes of the tree's wood and bark. Next, the bark was removed from the discs taken at relative heights of 20,50 and $80 \%$ of the total trunk height, the wood and bark were weighed separately with an accuracy of $0.1 \mathrm{~g}$, their volume was determined and dried to a constant weight in an oven at $110^{\circ} \mathrm{C}$. Then the absolute dry mass of the wood and bark were used to calculate a wood/bark proportion and the absolute dry phytomass of the wood and bark of the entire tree trunk.

The phytomass of tree crowns and their structural parts was determined after dividing the crowns into three sections of the same length, since crowns are heterogeneous in the vertical direction regarding the age and thickness of branches, branch coverage and qualitative composition of needles. After weighing each section of the crown (with an accuracy of $50 \mathrm{~g}$ ), they were divided into leafy/needled and non-leafy/non-needled branches. Then, a sample (about $0.5 \mathrm{~kg}$ ) was taken from each section's leafy/needled part to establish the ratio of needles and skeletal parts. For this purpose, we separated needles from the branches and then separately weighed these components' mass for each sample (with an accuracy of $1 \mathrm{~g}$ ). The phytomass of needles and woody parts was determined according to the established ratios for each section and the entire crown. To determine the moisture content and absolute dry weight of needles and branches, samples were taken from each part of the crown and then immediately weighed with an accuracy of $0.01 \mathrm{~g}$. Samples of branches were taken separately from leafy/needled and non-leafy/non-needled 
branches. The obtained values were used to calculate the absolute dry weight of the needles and tree branches. Weighed portions of needles and branches were dried to constant weight in thermostats at a temperature of $110^{\circ} \mathrm{C}$.

To determine the phytomass of subcanopy trees, they were subdivided into two groups. Firstly, in height, trees less than $0.5 \mathrm{~m}$ were fractionated (divided into a trunk, branches and foliage). After that, they were weighed, dried at $110^{\circ} \mathrm{C}$ to constant weight and the above-ground absolute dry phytomass was determined. From trees more than $0.5 \mathrm{~m}$ in height, leafy/needled shoots were cut off with pruning shears and a sample of $100-500 \mathrm{~g}$ was taken and weighed; then leaves/needles were removed from the sample and it was reweighed. Then the leaves/needles and the rest of the sample were dried separately to constant weight, weighed again and the absolute dry matter content in both fractions was calculated. Their values were used to determine the absolute dry weight of the crown of the entire plant. Together with non-leafy/non-needled shoots, the trunk mass was weighed in total, dried at $110^{\circ} \mathrm{C}$ to constant weight, summed with the crown's phytomass and then the above-ground absolute dry phytomass was determined.

Quality control: Plant species identification was carried out mainly in the field; specimens with controversial species affiliation were photographed or placed in a Herbarium and identified later in a laboratory by specialists from the Institute of Plant and Animal Ecology of the Ural Branch of the Russian Academy of Sciences (IPAE UB RAS).

In the following cases, occurrences were identified only to taxonomic ranks of high levels; first, the forest elements related to coarse woody debris (downed boles, fragments of downed boles and stumps). As a rule, these elements are destroyed and reliable determination of their taxonomic affiliation is difficult even down to the family level. Second, forest elements that were absent at the study sites were added to the dataset in order to record the very fact of their absence. In this case, we found it unnecessary to detail more than to the level of the type.

\section{Geographic coverage}

Description: The studied areas are located in the southern taiga subzone of the Southern Urals, in the vicinity of Karabash (polluted sites) and $20 \mathrm{~km}$ south of Karabash (sites with a background level of pollution). The same set of habitats represents both polluted and nonpolluted areas: pine, birch and floodplain forests, reed swamp, sparse birch stand, marshy meadow and dump of household waste.

Coordinates: 55.3222 and 55.4993 Latitude; 60.1092 and 60.2733 Longitude.

\section{Taxonomic coverage}

Description: General taxonomic coverage is 1 phylum, 2 classes, 7 orders, 8 families, 19 genera and 23 species of woody vegetation (Table 4 ). 
Table 4.

Distribution of occurrences with the lowest taxon rank identified

\begin{tabular}{|c|c|c|c|c|c|c|c|}
\hline \multirow[t]{2}{*}{ Group of forest elements } & \multirow[t]{2}{*}{ Forest element } & \multicolumn{6}{|c|}{ Taxon rank } \\
\hline & & Phylum & Class & Family & Genus & Species & Total \\
\hline \multirow[t]{2}{*}{ Forest stand } & Forest stand & & & & 498 & 745 & 1243 \\
\hline & Half-dead tree of a forest stand & 33 & & & 19 & 11 & 63 \\
\hline Subcanopy & Subcanopy & & & & 14 & 3410 & 3424 \\
\hline \multirow[t]{4}{*}{ Coarse woody debris } & Standing dead tree & 19 & & & 217 & 91 & 327 \\
\hline & Downed bole & 25 & 144 & 9 & & & 178 \\
\hline & Fragment of downed bole & 30 & 52 & 3 & & & 85 \\
\hline & Stump & 451 & 15 & & & & 466 \\
\hline Total & & 558 & 211 & 12 & 748 & 4257 & 5786 \\
\hline
\end{tabular}

It should be noted that the mature birch trees, presented in the dataset, are identified to genus. The birch is the only species which was not identified by biological species, but by genus (Novikova 2016) since different growing conditions determine a large variability of morphological characters in individual species. Vetchinnikova (Vetchinnikova 2004) noted that, "... the phylogeny and relationships of species in the genus Betula are rather complex; therefore its systematics is extremely difficult and requires new methodological approaches". Nevertheless, young plants of the genus Betula were quickly identified to species by the presence/absence of pubescence on the leaf blades.

It is also worth adding that only a few members of the genus Salix have been identified as species. The overlap of the ranges of many willow species and their close phylogenetic relationship contributed to the emergence of a significant number of natural hybrids in willows (about 90 hybrid forms have been described) (Antsiferov 1984), which significantly complicates the identification of their species.

Taxa included:

\begin{tabular}{|l|l|}
\hline Rank & Scientific Name \\
\hline class & Magnoliopsida \\
\hline order & Dipsacales \\
\hline family & Adoxaceae \\
\hline order & Fabales \\
\hline family & Fabaceae \\
\hline order & Fagales \\
\hline
\end{tabular}




\begin{tabular}{|l|l|}
\hline family & Betulaceae \\
\hline order & Malpighiales \\
\hline family & Salicaceae \\
\hline order & Rosales \\
\hline family & Rosaceae \\
\hline family & Ulmaceae \\
\hline order & Sapindales \\
\hline family & Sapindaceae \\
\hline class & Pinopsida \\
\hline order & Pinales \\
\hline family & Pinaceae \\
\hline
\end{tabular}

\section{Temporal coverage}

Data range: 2012-7-10 - 2012-7-20.

\section{Usage licence}

Usage licence: Creative Commons Public Domain Waiver (CC-Zero)

\section{Data resources}

Data package title: Biomass and mortmass of woody vegetation in metal-contaminated areas (Southern Urals, Russia)

Resource link: https://ipt.ipae.uran.ru/resource?r=frm bergman 2012\&v=1.4

\section{Number of data sets: 1}

Data set name: Woody vegetation under industrial pollution (Southern Urals, Russia): modifying influence of habitat conditions

Download URL: https://www.gbif.org/dataset/61384edd-2d0a-437b-8cf0-ff4d2dfcc0da

Data format: sampling event

\section{Data format version: 1.4}

Description: The dataset (Bergman and Nesterkov 2021) includes the results of an assessment of the woody vegetation biomass at seven habitats (pine, birch and floodplain forests, reed swamp, sparse birch stand, marshy meadow and dump of 
household waste) of areas with different levels of industrial pollution in vicinities of the Karabash, the Southern Urals. Karabash Copper Smelter (KCS) is one of Russia's most significant point polluters; the main components of its emissions are heavy metals, dust and sulphur dioxide. Parameters of woody vegetation (diameter at breast height, diameter at root collar level and biomass) were estimated for seven forest elements: forest stand, subcanopy, half-dead tree of a forest stand and four types of coarse woody debris (downed bole, fragment of downed bole, standing dead tree and stump) at 41 sampling plots (20 at non-polluted and 21 at polluted areas) and 165 subplots (81 and 84, respectively). The dataset includes 411 sampling events (estimation events of the forest elements at sampling plots and subplots), corresponding to 5786 occurrences (estimations of the woody vegetation components) observed during July 2012. For most woody vegetation components (72\%), an estimate of the above-ground phytomass is given. For each sampling event, information on the presence or absence of woody vegetation species at the considered habitats is provided. The dataset can be used for environmental monitoring, sustainable forest management, modelling forest productivity considering global changes, studying the structure and biodiversity of forest cover and assessing forests' carbon-sequestration capacity. In addition, the dataset provides information about different forest ecosystems under the influence of strong industrial pollution.

\begin{tabular}{|c|c|}
\hline Column label & Column description \\
\hline eventID & $\begin{array}{l}\text { An identifier for the set of information associated with an Event (an identifier of the } \\
\text { sampling plot with information about the forest element type encoded). }\end{array}$ \\
\hline occurrencelD & $\begin{array}{l}\text { An identifier for the Occurrence (an estimation of the forest element parameters } \\
\text { with information about the forest element type encoded). }\end{array}$ \\
\hline country & $\begin{array}{l}\text { The name of the country or major administrative unit in which the Location occurs } \\
\text { (Russian Federation). }\end{array}$ \\
\hline stateProvince & The specific description of the place (Chelyabinskaya Oblast'). \\
\hline municipality & $\begin{array}{l}\text { The full, unabbreviated name of the next smaller administrative region than county } \\
\text { in which the Location occurs (Karabash or Miass). }\end{array}$ \\
\hline locality & The specific description of the place (Karabash, Novoandreevka or Tyelga). \\
\hline countryCode & The standard code for the country in which the Location occurs (RU). \\
\hline ownerInstitutionCode & $\begin{array}{l}\text { The name (or acronym) in use by the institution having ownership of the object(s) } \\
\text { or information referred to in the record (Institute of Plant and Animal Ecology } \\
\text { (IPAE)). }\end{array}$ \\
\hline locationID & An identifier for the set of location information. \\
\hline basisOfRecord & The specific nature of the data record (HumanObservation). \\
\hline samplingProtocol & $\begin{array}{l}\text { The description of the method or protocol used during an Event (a complete } \\
\text { estimation of woody vegetation trunk diameters at breast height using a caliper). }\end{array}$ \\
\hline
\end{tabular}




\begin{tabular}{|c|c|}
\hline samplingEffort & $\begin{array}{l}\text { The amount of effort expended during an Event (a time period to estimate } \\
\text { parameters of all woody vegetation elements at the sampling plot). }\end{array}$ \\
\hline sampleSizeValue & $\begin{array}{l}\text { A numeric value for a measurement of the size of a sample in a sampling event (an } \\
\text { area of the sampling plot). }\end{array}$ \\
\hline sampleSizeUnit & $\begin{array}{l}\text { The unit of measurement of the size of a sample in a sampling event (square } \\
\text { metres). }\end{array}$ \\
\hline occurrenceRemarks & $\begin{array}{l}\text { Comments or notes about the Occurrence (a notes on the calculation and } \\
\text { availibility of biomass data). }\end{array}$ \\
\hline eventDate & The date-time during which an Event occurred. \\
\hline year & $\begin{array}{l}\text { The four-digit year in which the Event occurred, according to the Common Era } \\
\text { Calendar (2012). }\end{array}$ \\
\hline month & The ordinal month in which the Event occurred (7). \\
\hline decimalLatitude & $\begin{array}{l}\text { The geographic latitude (in decimal degrees, using the spatial reference system } \\
\text { given in geodeticDatum) of the geographic centre of a Location. }\end{array}$ \\
\hline decimalLongitude & $\begin{array}{l}\text { The geographic longitude (in decimal degrees, using the spatial reference system } \\
\text { given in geodeticDatum) of the geographic centre of a Location. }\end{array}$ \\
\hline geodeticDatum & $\begin{array}{l}\text { The ellipsoid, geodetic datum or spatial reference system (SRS) upon which the } \\
\text { geographic coordinates given in decimalLatitude and decimalLongitude are based } \\
\text { (WGS84). }\end{array}$ \\
\hline coordinateUncertaintylnMetres & $\begin{array}{l}\text { The horizontal distance (in metres) from the given decimalLatitude and } \\
\text { decimalLongitude describing the smallest circle containing the whole of the } \\
\text { Location ( } 10 \text { metres). }\end{array}$ \\
\hline maximumElevationInMetres & $\begin{array}{l}\text { The upper limit of the range of elevation (altitude, usually above sea level), in } \\
\text { metres. }\end{array}$ \\
\hline habitat & $\begin{array}{l}\text { A category of the habitat in which the Event occurred (pine forest, birch forest, } \\
\text { floodplain forest, reed swamp, sparse birch stand, marshy meadow and dump of } \\
\text { household waste). }\end{array}$ \\
\hline locationRemarks & $\begin{array}{l}\text { Comments or notes about the Location. The investigated areas are subdivided into } \\
\text { "polluted" and "non-polluted"; perimeters of the sampling plots or subplots (in } \\
\text { metres) are given. }\end{array}$ \\
\hline eventRemarks & $\begin{array}{l}\text { Comments or notes about the Event. A forest element within the event (forest } \\
\text { stand, subcanopy, half-dead tree of a forest stand, downed bole, fragment of } \\
\text { downed bole, standing dead tree and stump). }\end{array}$ \\
\hline scientificName & The full scientific name, with authorship and date information. \\
\hline scientificNameAuthorship & $\begin{array}{l}\text { The authorship information for the scientificName formatted according to the } \\
\text { conventions of the applicable nomenclaturalCode. }\end{array}$ \\
\hline
\end{tabular}




\begin{tabular}{|c|c|}
\hline recordedBy & $\begin{array}{l}\text { A list (concatenated and separated) of names of people, groups or organisations } \\
\text { responsible for recording the original Occurrence. }\end{array}$ \\
\hline identifiedBy & $\begin{array}{l}\text { A list (concatenated and separated) of names of people, groups or organisations } \\
\text { who assigned the Taxon to the subject. }\end{array}$ \\
\hline kingdom & The full scientific name of the kingdom in which the taxon is classified. \\
\hline phylum & The full scientific name of the phylum or division in which the taxon is classified. \\
\hline class & The full scientific name of the class in which the taxon is classified. \\
\hline order & The full scientific name of the order in which the taxon is classified. \\
\hline family & The full scientific name of the family in which the taxon is classified. \\
\hline genus & The full scientific name of the genus in which the taxon is classified. \\
\hline specificEpithet & The name of the first or species epithet of the scientificName. \\
\hline taxonRank & The taxonomic rank of the most specific name in the scientificName. \\
\hline occurrenceStatus & A statement about the presence or absence of a Taxon at a Location. \\
\hline measurementValue & $\begin{array}{l}\text { The value of the measurement, fact, characteristic or assertion (measurements of } \\
\text { the tree trunk diameters). }\end{array}$ \\
\hline measurementType & $\begin{array}{l}\text { The nature of the measurement, fact, characteristic or assertion (two types of } \\
\text { estimations of the tree trunk diameters, the DBH (diameter at breast heght) and the } \\
\text { diameter at root collar level). }\end{array}$ \\
\hline measurementAccuracy & The description of the potential error associated with the measurementValue. \\
\hline measurementUnit & The units associated with the measurementValue (centimetre). \\
\hline measurementDeterminedBy & $\begin{array}{l}\text { A list (concatenated and separated) of names of people who determined the value } \\
\text { of the MeasurementOrFact (Igor E. Bergman). }\end{array}$ \\
\hline measurementMethod & $\begin{array}{l}\text { A description of the method or protocol used to determine the measurement, fact, } \\
\text { characteristic or assertion ("caliper," "pole caliper" or "caliper | measuring tape"). }\end{array}$ \\
\hline measurementRemarks & $\begin{array}{l}\text { Comments or notes accompanying the MeasurementOrFact (if possible, each } \\
\text { forest element's specimen is assigned to decidious or coniferous). }\end{array}$ \\
\hline identificationRemarks & Comments or notes about the Identification. \\
\hline organismQuantity & $\begin{array}{l}\text { A number or enumeration value for the quantity of organisms (the biomass of forest } \\
\text { element's specimens). }\end{array}$ \\
\hline organismQuantityType & The type of quantification system used for the quantity of organisms (kilogram). \\
\hline
\end{tabular}

\section{Acknowledgements}

The research was supported by Russian Foundation for Basic Research (RFBR), projects no. 12-05-00811 and 08-04-91766. 
We express our gratitude to N.V. Zolotareva for help in identifying the species of woody plants, T.Yu. Gaberstein for active participation in forest inventory work, A.F. Urazova, A.V. Bornikov, A.S. Zhanabaeva, A.S. Kasatkin, E.V. Barakovskikh and N.V. Nakay for help in processing model plants. We thank Professor V.A. Usoltsev for organising the sampling and processing of model plants. We are grateful to Yu.A. Davydova and S.V. Mukhacheva, who provided organisational and financial support for the work.

\section{Author contributions}

Igor Bergman - fieldwork, species identification, dataset compilation, manuscript preparation. Alexey Nesterkov - dataset preparation, dataset publishing, manuscript preparation.

\section{References}

- $\quad$ Antsiferov GI (1984) Iva. [Willow]. Lesnaya Promyshlennost, Moskow, 101 pp. [In Russian].

- Bergman I, Nesterkov A (2021) Woody vegetation under industrial pollution (Southern Urals, Russia): modifying influence of habitat conditions. Dataset/Samplingevent. 1.1. Institute of Plant and Animal Ecology (IPAE). URL: https://ipt.ipae.uran.ru/resource? r=frm bergman $2012 \& v=1.1$

- $\quad$ Bergman IE, Vorobeychik EL, Zhdanova TY (2013) Izmeneniye stroyeniya drevostoyev pod deystviyem atmosfernogo zagryazneniya: modifitsiruyushcheye vliyaniye usloviy ekotopa [Changes in the structure of forest stands under the influence of atmospheric pollution: the modifying effect of ecotope conditions]. Mezhdunarodnyy Zhurnal Prikladnykh i Fundamental'nykh Issledovaniy (8)25-27. [In Russian].

- Bobkova KS, Kuznetsov MA, Osipov AF (2015) Zapasy krupnykh drevesnykh ostatkov v yel'nikakh sredney taygi Yevropeyskogo Severo-Vostoka [Stocks of coarse woody debris in the spruce forests of the middle taiga of the European North-East]. Izvestiya Vysshikh Uchebnykh Zavedeniy. Lesnoy Zhurnal (2)9-21. [In Russian].

- $\quad$ Fowler A, Low K, Stone J (2002) Earth observation for sustainable development: Using space-based technology for monitoring Canada's forests. Information Forestry6-7.

- Harmon ME, Franklin JF, Swanson FJ, Sollins P, Gregory SV, Lattin JD, Anderson NH, Cline SP, Aumen NG, Sedell JR, Lienkaemper GW, Cromack K, Cummins KW (2004) Ecology of coarse woody debris in temperate cosystems. Advances in Ecological Research59-234. https://doi.org/10.1016/s0065-2504(03)34002-4

- Karjalainen L, Kuuluvainen T (2002) Amount and diversity of coarse woody debris within a boreal forest landscape dominated by Pinus sylvestris in Vienansalo wilderness, eastern Fennoscandia. Silva Fennica 36 (1). https://doi.org/10.14214/sf.555

- Klimchenko AV, Verkhovets SV, Slinkina OA, Koshurnikova NN (2011) Zapasy krupnykh drevesnykh ostatkov v srednetayezhnykh ekosistemakh Priyeniseyskoy Sibiri [Stocks of coarse woody debris in the middle taiga ecosystems of the Yenisei Siberia]. Geografiya i Prirodnyye Resursy (2)91-97. [In Russian].

- Kofman GB (1986) Rost i forma derev'yev. [Growth and shape of trees]. Nauka, Novosibirsk, 211 pp. [In Russian]. 
- Mukhacheva SV, Davydova YA, Kshnyasev IA (2010) Responses of small mammal community to environmental pollution by emissions from a copper smelter. Russian Journal of Ecology 41 (6): 513-518. https://doi.org/10.1134/s1067413610060081

- Mukhacheva SV, Davydova YA, Vorobeichik EL (2013) The role of heterogeneity of the environment in preservation of the diversity of small mammals under the conditions of strong industrial pollution. Doklady Biological Sciences 447 (1): 338-341. https://doi.org/ 10.1134/s0012496612010206

- $\quad$ Novikova MA (2016) Osobennosti yestestvennogo vozobnovleniya berezy v usloviyakh Leningradskoy $i$ Tverskoy oblastey. [Features of natural regeneration of birch in the conditions of the Leningrad and Tver regions]. St. Petersburg State Forestry University, Saint Petersburg, 19 pp. [In Russian].

- S Sitonen J (2001) Forest management, coarse woody debris and saproxylic organisms: Fennoscandian boreal forests as an example. Ecological Bulletins 49: 11-41. https:// doi.org/10.2307/20113262

- $\quad$ Stokland JN, Siitonen J, Jonsson BG (2012) Biodiversity in dead wood. Cambridge University Press, Cambridge, 509 pp. https://doi.org/10.1017/CBO9781139025843

- Usoltsev VA, Zalesov SV (2005) Metody opredeleniya biologicheskoy produktivnosti nasazhdeniy. [Methods for estimating the biological productivity of forest stands]. Izdatel'stvo Ural'skogo Gosudarstvennogo Lesotekhnicheskogo Universiteta, Ekaterinburg, 147 pp. [In Russian].

- Usoltsev VA, Vorobeychik EL, Bergman IE (2012) Biologicheskaya produktivnost' lesov Urala v usloviyakh tekhnogennogo zagryazneniya: issledovaniye sistemy svyazey $i$ zakonomernostey. [Biological productivity of the forests of the Urals in the conditions of technogenic pollution: a study of the system of connections and patterns]. Izdatel'stvo Ural'skogo Gosudarstvennogo Lesotekhnicheskogo Universiteta, Ekaterinburg, 365 pp. [In Russian].

- Usoltsev VA, Chasovskikh VP, Tsepordei IS (2018) Fitomassa lesnykh derev'yev i biogeografiya: issledovaniye sistemnykh svyazey sredstvami informatsionnykh tekhnologiy: monografiya. [Phytomass of forest trees and biogeography: a study of systemic relationships through information technology: a monograph]. Izdatel'stvo Ural'skogo Gosudarstvennogo Lesotekhnicheskogo Universiteta, Ekaterinburg, 456 pp. [In Russian].

- Vetchinnikova LB (2004) Bereza: voprosy izmenchivosti (morfo-fiziologicheskiye i biokhimicheskiye aspekty). [Birch: questions of variability (morpho-physiological and biochemical aspects]. Nauka, Moscow, 183 pp. [In Russian].

- Zamolodchikov DG (2009) Otsenka pula ugleroda krupnykh drevesnykh ostatkov v lesakh Rossii s uchetom vliyaniya pozharov i rubok [Estimation of the carbon pool of coarse woody debris in the forests of Russia taking into account the influence of fires and fellings]. Lesovedenie (4)3-15. [In Russian]. 